\title{
Wolfgang Havener, Imperator Augustus. Die diskursive Konstituierung der militärischen persona des ersten römischen Princeps, (Studies in Ancient Monarchy - 4), Franz Steiner Verlag, Stuttgart 2016, 424 pp; ISBN 978-3-515-11220-8
}

The two thousandth anniversary of the death of Caesar Augustus in 2014 provided scholars with an excellent opportunity to revisit the subject of his political position and his accomplishments. Among the impressive number of publications directly and indirectly related to this jubilee is Wolfgang Havener's work Imperator Augustus. This is an expanded version of his doctoral dissertation submitted in 2013 at the University of Konstanz. It was no doubt the book's subject matter as well as the anniversary that resulted in its swift publication.

Among the fundamental components of the political leadership of the first princeps was his rule over the army. This was crucial in assuring him control over the state and was an effective tool allowing him to influence both domestic and foreign policy. The political career of Octavian, later to become Emperor Augustus, demonstrates that the beginning of the process of his acquisition of rule over the army stretched back to its first days. Havener took the trouble to track how this process unfolded, analysing the various phases of Octavian's political career, taking as its beginning his adoption of the praenomen imperatoris during battles against Sextus Pompey (p. 12). The successive military phases of civil war gave him further opportunities to build his authority as a victorious leader. He made use of each of them not only politically, but for propaganda purposes too.

The dissertation comprises eight extensive chapters (Chapters 3 to 7 are divided into a number of subchapters in which the author analyses various detailed issues). In Chapter 1, "Einleitung" (pp. 9-34), he presents his research objectives and methodology. The former encompass a wide range of topics, although they essentially boil down to finding an answer to questions about the nature of Augustus' military authority, the relations between him and the senatorial aristocracy, as well as the effect the model based on the first princeps ' rule over the army had on his successors' style of rule. ${ }^{1}$

1 Cf. "Zugespitzt kann man formulieren: Eine Analyse der militärischen persona des ersten princeps liefert insofern einen Beitrag zum Verständnis der römischen Monarchie, als die Verständigungsprozesse zwischen dem Herrscher und der senatorischen Elite eine der Grundlagen für ihre Stabilität bildeten. Eine Untersuchung dieser spezifischer persona ermöglicht es folglich, die tatsächliche Machtgrundlage mit den Rollenmodell zusammenführen, das die wesentliche Form der Ausgestaltung monarchischer Herrschaftspraxis in der römischen Kaiserzeit darstellte" (p. 34). 
In Chapter 2 ("Schweres Erbe - Der Feldherr Caesar als Herausforderung für Augustus," pp. 35-50), the author discusses Augustus' relationship with his adoptive father Julius Caesar and his deeds, as well as his use of these family ties in his own actions. The next section is the longest, devoted to Octavian's military activity and closely related propaganda campaigns during the second triumvirate, and later in the course of the struggle for power with Antonius ("Feldherr, Führer, Kriegsbeender - Die Rolle Octavians während des zweiten Triumvirats und im Krieg gegen Antonius," pp. 51-150). The objective of his actions was firstly to legitimise his position, and in the longer run to seek to construct ideological foundations for his leadership. Octavian's work to achieve these goals was particularly intense during his rivalry with Antony. Concordia was one of his most-used slogans at the time. The concord in question was not only supposed to be a way to restore domestic peace and social order in the state, but also to become a foundation of the new political order based on Octavian's leadership. This watchword was contrasted with discordia, a synonym of the chaos resulting from the political rivalry of the alliances, the source of which was the deficiencies of the republican order. In the next chapter ("Augustus und Octavian - Der Umgang des princeps mit seinem Weg zur Macht," pp. 151-192), the author analyses Octavian's activity from the perspective of his Res gestae as well as the biography of Augustus by Nicolaus of Damascus, showing that he was initially motivated by the desire for revenge on the killers of Caesar and the wish to secure the right to his bequest. It was these elements that won him the sympathy and support of society, which, with the help of the army, he made a foundation of his political position. In his Res gestae, however, Augustus presents himself as a restorer of the res publica operating on the mandate received from the senate. Chapter 5 ("Parta victoriis pax - Zur Enstehung eines 'Grundbegriffs' augusteische Herrschaftsemantik," pp. 193-252) focuses on discussing Augustus' most important propaganda slogan - parta victoriis pax - by analysing the ideological contents in Res gestae, art works (Ara Pacis Augustae, Gemma Augustea), minting, and the honorary titles he received (pater patriae). Augustus' restraint towards the Parthian state aroused a great deal of emotion and criticism in his entourage. Yet despite pressure from various sides, he did not opt for armed conflict with the eastern neighbour. By using diplomatic methods, however, he managed to secure such successes in his relations with the Parthians that he was able to completely abandon military plans towards them, as well as using them for propaganda purposes in preserving his image as a victorious leader in society ("Sieger ohne Krieg Die Präsentation des 'Parthersieges'," pp. 253-275). An important role in the creation of this image was played in $20 \mathrm{BCE}$ when Phraates IV, king of the Parthians, returned the standards lost by legions during the campaign of Marcus Crassus and Mark Antony (Res gestae 29.2). A different element of this image was Augustus' practice of monopolising the exclusive right to celebrate the triumphs due to him owing to his authority over the army ("Triumphator perpetuus - Augusteische Triumphpolitik," pp. 277-362). Some time passed before this monopoly was established, however, in addition to the way in which it was enforced. In the first years of Augustus' rule, several of his commanders still had the privilege of a triumph, the last of them in 19 BCE. The fear that the triumphant leaders could gain popularity among soldiers was not without influence on the princeps' decision to replace the right to triumph with awarding commanders with a symbolic or- 
namenta triumphalia. ${ }^{2}$ From that time, the right to a triumph became the sole privilege of the ruler, and imperatorial acclamations became part of his official titulature. The eighth and final chapter contains a summary ("Die militärische persona des ersten princeps Fazit und Ausblick," pp. 363-376). After analysing the sources and comparing the results of his research with other scholars' views on the nature of the system of rule established by Augustus, the author has no doubt that this system was a military dictatorship. ${ }^{3}$

This book is the first to analyse at length and systematically the military aspects of the political position of the first princeps. The author confirms in many details what was previously known on the subject, yet at the same time he also presents many new observations and conclusions proving that the process by which Octavian/Augustus gained power over the army was a gradual one consisting of many stages. Moreover, certain elements were not planned in advance, but appeared with time and under the influence of various circumstances. There is no doubt that, although this is a book that demands a great amount of attention and effort from the reader, it is one with which scholars dealing with Augustus' era ought to familiarise themselves.

Edward Dąbrowa

iD http:/orcid.org/0000-0002-9324-9096

Jagiellonian University in Kraków

2 Cf. "Entgegen der in der Forschung vorherrschenden Meinung, Augustus habe von Anfang an das Ziel verfolgt, dieses Ritual für sich zu monopolisieren, konnte deutlich gemacht werden, dass von einer Triumphpolitik , aus einem Guss “ unter dem ersten princeps keine Rede sein konnte” (p. 368).

3 “...lässt sich am Ende dieser Untersuchung eines festhalten: In jedem Fall war das römische Kaisertum eine militärische Diktatur, in der dem militärischen Sektor wie wenn nicht die entscheidende Rolle zufiel" (p. 376). 